\title{
Assessing the Agricultural Water Savings-Economy-Ecological Environment System in an Arid Area of Northwest China Using a Water Rights Transaction Model
}

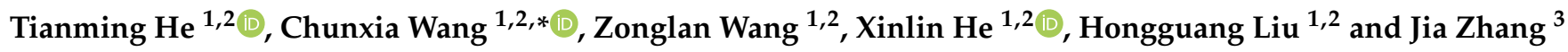 \\ 1 College of Hydraulic Engineering, Shihezi University, Shihezi 832000, China; aming202003@163.com (T.H.); \\ wang_zonglan@163.com (Z.W.); hexinlin2002@163.com (X.H.); liuhongguang-521@163.com (H.L.) \\ 2 Key Laboratory of Modern Water-Saving Irrigation Corps, Shihezi 832000, China \\ 3 The Eighth Division Wster Bureau, Shihezi 832000, China; jia20210427@163.com \\ * Correspondence: wangchunxia1979@139.com
}

\section{check for} updates

Citation: He, T.; Wang, C.; Wang, Z.; He, X.; Liu, H.; Zhang, J. Assessing the Agricultural Water Savings-Economy-Ecological Environment System in an Arid Area of Northwest China Using a Water Rights Transaction Model. Water 2021, 13, 1233. https://doi.org/ 10.3390/w13091233

Academic Editor:

Dionysia Panagoulia

Received: 18 March 2021

Accepted: 26 April 2021

Published: 29 April 2021

Publisher's Note: MDPI stays neutral with regard to jurisdictional claims in published maps and institutional affiliations.

Copyright: (c) 2021 by the authors. Licensee MDPI, Basel, Switzerland. This article is an open access article distributed under the terms and conditions of the Creative Commons Attribution (CC BY) license (https:// creativecommons.org/licenses/by/ $4.0 /)$.

\begin{abstract}
As water trading has become increasingly used to optimize the allocation of water resources, it has become necessary to transfer agricultural water allocations for economic development and ecological environmental uses by way of water rights trading. In this paper, we constructed an example water rights trading model in the arid oasis area of Shihezi Irrigation District (located in Northwest China), using the field investigation method and governmental water management decisions based on the systems theory of the agricultural water savings-economy-ecological environment. Furthermore, focusing on the added industrial value produced by trading water, the value of the ecological services provided by fresh water, the negative value of the reduction in greenhouse gas emissions, and the negative ecological value of reduced fertilizer application, a quantitative analysis was carried out using the Shihezi Irrigation District as an example. The results showed that under the most stringent water resource management plan and with the objective of returning land and reducing water, the irrigation area can save $52,504,500 \mathrm{~m}^{3}$ of surplus water from the agricultural sector, of which $49,879,300 \mathrm{~m}^{3}$ can be reallocated to the industrial sector and 2,625,200 $\mathrm{m}^{3}$ can be reallocated to the ecological sector. Using the water rights transaction method, this regional agricultural water saving could generate an industrial benefit equal to 35,024,300 yuan, an ecosystem service equal to $19,482,200$ yuan, and an overall benefit equal to $54,420,500$ yuan. The water rights trading model proposed in this paper for an arid oasis areas can provide a reference for other arid areas, helping to achieve the sustainable economic development of the economic and ecological environments in arid oasis areas through water rights trading.
\end{abstract}

Keywords: water rights transaction; agricultural water savings-economy-ecological environment; arid oasis area; water policy; system theory; Northwest China

\section{Introduction}

Water is a basic resource for economic and social development and a controlling element of the ecological environment. The arid oasis area in Northwest China is an ecologically sensitive and environmentally degraded area, and a core area for economic development. The rational use of water resources plays a vital role in the sustainable development of the region. Moreover, anticipated events such as climate change and unexpected events such as COVID-19 have exacerbated the urgent need for efficient and rational use of water resources [1]. In many parts of the world, managing water demand by increasing supply is no longer possible, or can only be done by paying a greater price than in the past [2]. In particular, industrial water consumption is increasing significantly alongside continuous social and economic development. For arid areas that lack natural water resources, new sources of water have to be sought. One option is to obtain water from the agricultural sector through water rights trading [3]. In the development of international 
water rights and water rights markets, water rights transactions in Australia are generally considered as a model. Grafton [4] constructed a relatively complete water rights market framework by assessing market conditions using 26 indicators in four groups: institutional, economic efficiency, fairness, and environmental sustainability indicators. The evaluation found that the goals of policy makers and the establishment of relevant institutions have a significant impact on the role of the water market. In addition, even a mature water market needs to be strengthened by market governance and water rights systems. Wheeler [5] proposed an evaluation framework for the establishment of water rights trading markets, analyzing the potential obstacles in the construction of water markets and evaluating the feasibility of water rights trading in developing areas. The authors believed that when environmental water use goals are increasingly made a feature of policy, the market-based redistribution method provides an attractive and practical means of facing uncertainties in the future. Connell [6], Wheeler [7], and Grafton [8] took the Murray-Darling Basin in Australia as an example and indicated that market-oriented water rights market performance is better than government-led water resource management performance. Water rights trading can promote water resource utilization efficiency, promote rational distribution of water resources, improve the environment, and reduce water losses due to drought. Zeng [9] proposed a joint probability interval multistage method, taking the Kaidu-Kongkong River Basin in Xinjiang as an example through which to study the contribution of water rights trading to the sustainable development of the region. The results showed that a reasonable water resource trading scheme is an effective way to allocate limited water resources with the goal of maximizing system benefits.

Another core issue of water rights trading is the determination of water rights trading prices. Reasonable water rights transaction prices are the basis for the optimal allocation of water resources and realization of sustainable development of the social economy and ecological environment. In recent years, Chen [10] and Liu [11] used economic theories to establish a game model to predict transaction prices for water rights trading; $\mathrm{Wu} \mathrm{[12]}$ applied the theory of complexity and adaptability to construct a bilateral bidding auction model for water rights market transactions and analyzed the price formation mechanism of water rights transactions; $\mathrm{Xu}$ [13] used a random forest regression algorithm model to predict the price of water rights transactions in the western USA; Shen [14] introduced the concept of a benchmark water price and established a water quantity measurement model based on the actual transaction value of water to determine the water rights transaction price; Zhang $[15,16]$ and others used the production function (Cobb-Douglas function) and emergy theory to construct a price model for water rights transactions between China's agricultural and industrial sectors, including transaction costs and profit prices. Furthermore, taking the northern part of China as an example for empirical analysis, the reasonable water transaction price should be an interval value. In general, the current research on water rights transactions has mainly concentrated on the market between agriculture and industry, which is the most feasible market form in theory because the market between agriculture and industry has the greatest potential [3]. Because agricultural production consumes large amounts of water and fertilizer resources and has a negative impact on the soil environment, scholars have carried out feasibility studies on the transfer of agricultural water savings to ecology. A good ecological environment has a certain ecosystem service function. With an increasing amount of water transferred from agriculture to ecology, the conservation function of water resources plays a positive role in arid areas, for example in controlling soil desertification, restoring dry downstream lakes, and improving local climatic conditions. At the same time, from the perspective of greenhouse gas emissions, natural desert ecosystems produce lower $\mathrm{CH}_{4}$ and $\mathrm{N}_{2} \mathrm{O}$ emissions than farmland ecosystems [3,17-20].

Water rights trading is a multidisciplinary research area involving farmland water conservancy, economics, management, and ecology. In the 1990s, Costanza [21] put forward the idea of system theory. Researchers began to treat the complex system of water resources-economic society-ecological environment from a systematic perspective. 
Nepal [22] studied water security issues in Nepal from the perspective of the relationship between water, energy, and agriculture (food). Effective water management and governance requires a connection-based approach. $\mathrm{Li}[23,24]$ explored the nature of the water resources-economic society-ecological environment system and analyzed the mutual feedback mechanisms of system evolution between the three components in a long-term time series in Xinjiang. Moreover, we should not overemphasize the free market in the ideal sense in the process of building a water rights transaction model, and must combine the constraints of national conditions and factors associated with Chinese characteristics [25]. In the 1990s, Xinjiang introduced drip irrigation water-saving planting technology, vigorously reclaimed wasteland, and developed planting agriculture, which led to a significant increase in agricultural water consumption and unconventional cultivated land area, which further affected the water use structure, rendering the regional planting structure and industrial structure infeasible. Agricultural water consumption accounts for more than $90 \%$ of total water consumption throughout the year [26,27], and water shortages and the irrational use of water resources have become serious safety issues that restrict Xinjiang's environmental quality and economic and social development. Therefore, taking the Shihezi Irrigation District in Xinjiang as an example and using water to determine land and water to determine development, this study explored the coordinated development relationship of the agricultural water savings-economy-ecological environment system to establish a water rights model for the arid oasis area in Xinjiang, Northwest China. Furthermore, we utilized the transaction model, analyses of water-saving benefits, exploration of new development concepts, rational allocation of water resources through water transactions, and water management models to provide references for sustainable economic development in arid oasis areas.

\section{Modes and Methods}

\subsection{Construction of a Water Rights Transaction Model in an Arid Oasis Area in Xinjiang, China}

The ecological environment in arid areas is fragile. Arid zones around the world are responsible for $44 \%$ of contributions to global warming, and have been the most significant areas in this regard over the past 100 years. Precipitation is an important factor affecting arid areas [28]. Moreover, $38 \%$ of the world's population are from arid zones, and these are some of the most sensitive areas in terms of human activities and climate change. In recent years, arid zones have been expanding and showing a trend of accelerated expansion [29]. However, as a result of the long-term reclamation of wasteland by humans, water resource shortages have been aggravated and original ecological environments have been destroyed. In accordance with the actual situation of the region, Xinjiang issued the Implementation Plan for Comprehensive Agricultural Water Price Reform in Xinjiang Uygur Autonomous Region (New Deal) in 2017 (Fa [2017] No. 29) and Guiding Opinions on Water Right Reform and Water Market Construction in Xinjiang Uygur Autonomous Region (Xinzheng Fa [2017] No. 30). In 2018, the completion of land rights confirmation of the Eighth Division of Xinjiang Construction Corps laid the foundation for plan to "return land and reduce water". On the basis of governmental water management decisions, economic and social development planning, and ecological environmental protection goals, a water rights trading model was constructed for the arid oasis in Xinjiang, China (Figure 1). 
Water Management Policy

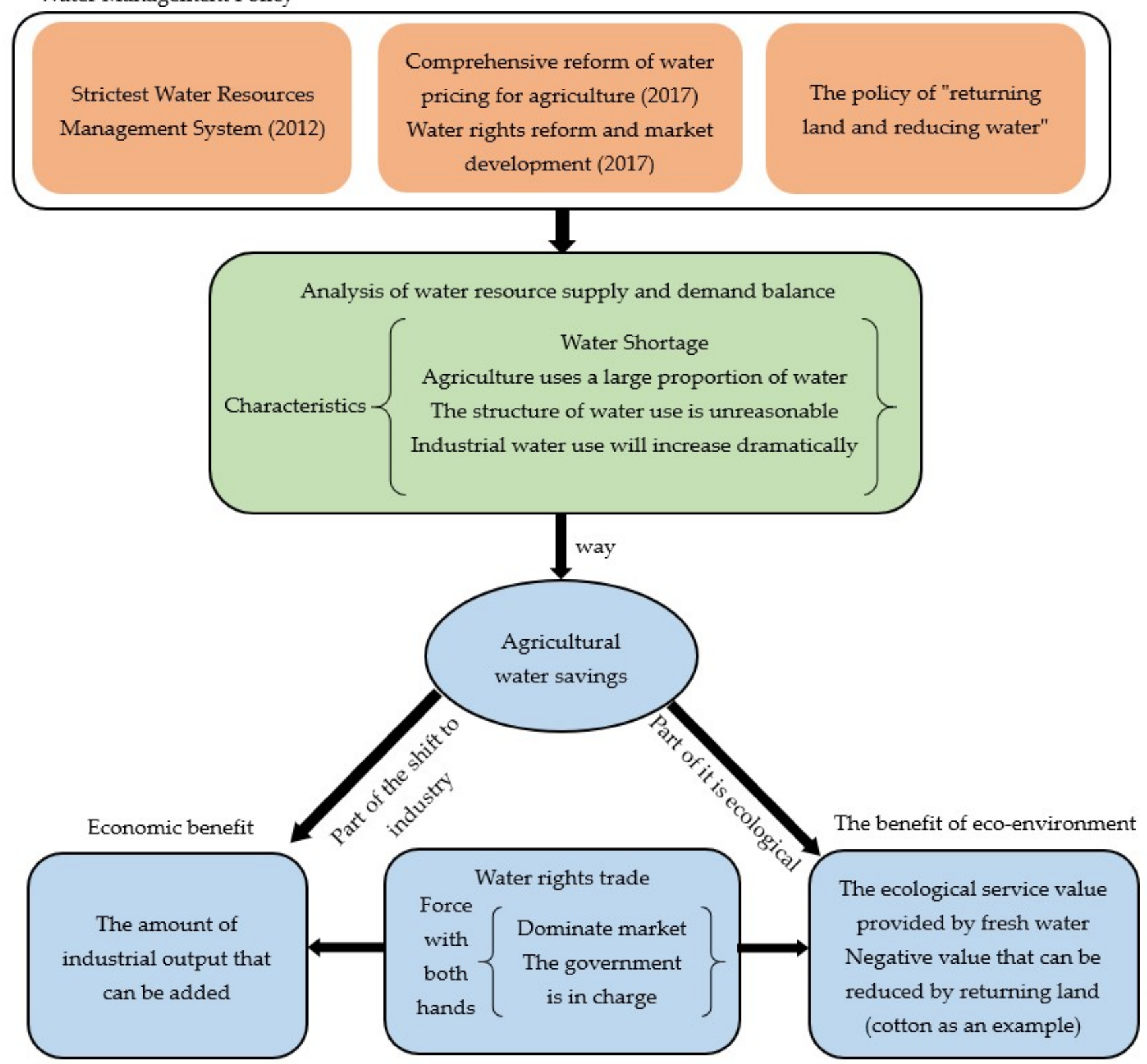

Figure 1. Water rights trading model in the arid oasis area of Xinjiang, China.

2.2. Overview of the Study Area-Taking Shihezi Irrigation District (Located in Northwest China) as an Example

The Shihezi Irrigation District is one of the largest irrigation districts in the Manas River Basin in Xinjiang, and the sixth largest irrigation district in China. The Shihezi Irrigation District is the same administrative region as Shihezi City in the Xinjiang Uygur Autonomous Region. It is located at $84^{\circ} 43^{\prime}-86^{\circ} 35^{\prime}$ east longitude and $43^{\circ} 21^{\prime}-45^{\circ} 20^{\prime}$ north latitude. From south to north, the district contains the Tianshan Mountains, hilly piedmont areas, sloping piedmont plains, and alluvial flood plains. The average altitude is $450.8 \mathrm{~m}$. The irrigation area is cold in the winter and dry and hot in the summer. The annual average temperature is about $7^{\circ} \mathrm{C}$. The annual average precipitation is $154 \mathrm{~mm}$, and the evaporation is $1600 \sim 2000 \mathrm{~mm}$. More than $90 \%$ of the irrigation area has adopted drip irrigation and water-saving irrigation technology. More than $80 \%$ of the area's crop production is cotton, which is typical of the Xinjiang desert oasis agricultural irrigation area. In 2018, the total economic and social water consumption of the Shihezi Irrigation District accounted for 78\% 
of the area's total water resources, far exceeding the internationally recognized standard that water resource development and utilization in any region should not exceed $40 \%$. Furthermore, domestic experts believe that the water resource development and utilization rate in the arid area of Northwest China should not exceed 70\% [30,31]. This paper divides the Shihezi Irrigation District into three areas: Shizongchang (Beiquan Town), 152 Regiment (Shihezi Town), and 143 Regiment North Irrigation District (Huayuan Town), as shown in Figure 2.

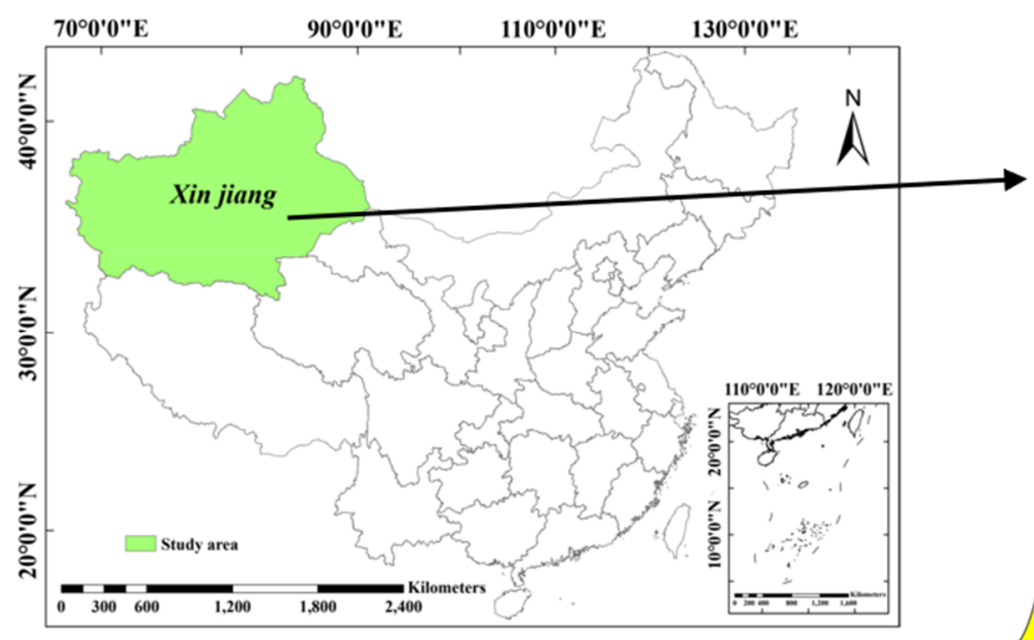

Shi Zong Chang

\section{Regiment Northern Irrigation District (Hua-yuan town)}

\section{Regiment (Shihezi town)}

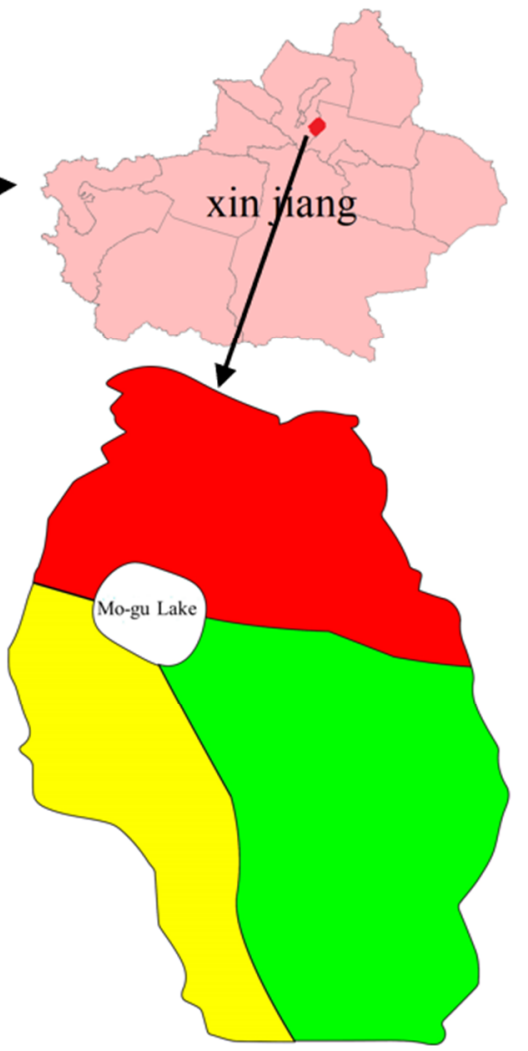

Figure 2. Diagram of the Shihezi Irrigation Area.

\subsection{Analysis Method}

\subsubsection{Calculation of Regional Agricultural Water-Saving Potential}

The calculation of agricultural water-saving potential is the basis for the conversion of agricultural water for nonagricultural purposes. According to the government's water management scheme, the transferable agricultural water saved in this irrigation area can be divided into two parts: the amount of water that can be saved from the actual amount of irrigation water under the management irrigation quota; and the amount of water that can be saved under the measures of returning land and reducing water [32,33]. Under the protection of food security, the returning land is mainly used to grow cotton-based economic crops. Therefore, the water consumption savings component was calculated using cotton. In summary, the proposed formula for calculating the total regional water savings under the government water management scheme is as follows:

$$
\begin{aligned}
& Q_{J}=Q_{G}+Q_{T} \\
& Q_{T}=\frac{q_{C} \cdot M_{D}}{\eta}
\end{aligned}
$$

where $Q_{J}$ is the total water savings that can be traded in the area in $\mathrm{m}^{3} ; Q_{G}$ is the amount of water that can be saved under fixed irrigation in the irrigation area in $\mathrm{m}^{3} ; Q_{T}$ is the amount 
of water that can be saved by returning farmland in $\mathrm{m}^{3} ; q_{C}$ is the net irrigation quota for cotton in $\mathrm{m}^{3} / \mathrm{hm}^{2} ; \eta$ is the irrigation water utilization coefficient of Shihezi Irrigation District, 0.653 [34]; and $M_{D}$ is the planned area of retired land in the irrigation district in $\mathrm{hm}^{2}$;

In the context of ecologically minded civilization construction and sustainable development, the transfer of water saving from agriculture to industry must also take into account the sound development of the ecological environment, because the development at the expense of the ecological environment is not sustainable. Therefore, it is necessary to determine the amount of water transferred from agricultural water-saving to industrial water demand and ecological water demand. The calculation formula is as follows:

$$
\begin{aligned}
& Q_{g y}=Q_{J} \cdot I_{1} \\
& Q_{s t}=Q_{J} \cdot I_{2}
\end{aligned}
$$

where $Q_{g y}$ is the amount of saved agricultural water that becomes industrial water in $\mathrm{m}^{3}$; $Q_{J}$ is the total water savings that can be traded in the region in $\mathrm{m}^{3} ; I_{1}$ is the transfer ratio of industrial water consumption; $Q_{s t}$ is the amount of saved agricultural water transferred to ecological water consumption in $\mathrm{m}^{3}$; and $I_{2}$ is the transfer ratio of ecological water consumption.

\subsubsection{Industrial Benefit Calculation Method}

According to previous researchers' $[35,36]$ predictions concerning future water resource utilization in the region, and in combination with the 14th Five-Year Plan of Xinjiang Production and the Construction Corps, the region is expected to see vigorous development of a modern industrial system. Industrial water use will increase substantially, which will become a major driving force for future water use in the arid oasis area. The calculation of the industrial benefits in this study consisted of two parts: the conversion of agricultural water into industrial water, which increases the value of the water resources, $V_{O}$; and the industrial added value generated by the transfer of water, $V_{b}$.

$$
\begin{gathered}
V_{O}=\left(P_{s}-P_{n}\right) \cdot Q_{g y} \\
V_{b}=\frac{Q_{g y}}{q_{g y}} \\
V_{g y}=V_{o}+V_{b}
\end{gathered}
$$

where $V_{g y}$ is the added value of total industrial water in yuan; $P_{s}$ is the transaction price of agricultural water turned into industrial water in yuan $/ \mathrm{m}^{3} ; P_{n}$ is the current value of agricultural irrigation water in the irrigation area in yuan $/ \mathrm{m}^{3} ; Q_{g y}$ is the amount of agricultural water savings diverted to industrial water in $\mathrm{m}^{3}$; and $q_{g y}$ is the amount of water needed to produce 10,000 yuan of value in $\mathrm{m}^{3}$.

\subsubsection{Ecological Benefit Calculation Method}

The positive development of the ecological environment is related to the fundamental and long-term interests of human survival and development. The U.S. Environmental Protection Agency provides a simple definition of ecological benefits in their ecological benefit evaluation strategic plan [37]: "The contribution of ecosystems to social well-being". Ecological benefit evaluation is a method to evaluate the changes in social welfare caused by EPA policies and to give qualitative and quantitative description. As China incorporates ecological benefits into its social and economic development evaluation index system, a large number of studies focusing on the evaluation of the value of ecosystem services have been published. From the perspective of water trade, this research measures the benefits of the transition from agricultural water savings to ecological water use under the government's water management scheme. Freshwater resources have their own resource value. In addition, farmland is not only an important place for soil carbon sequestration, 
but also one of the sources of greenhouse gas emissions. Measures to return land and reduce water can reduce greenhouse gas emissions and alleviate climate change, which positively affects the overall ecological environment of the arid oasis area. In general, the two main considerations are the ecological service value that freshwater can provide and the negative value of cultivated land ecosystem services.

The value of ecological services that freshwater can provide. The value of ecological services provided by freshwater is mainly determined based on the price of drinking water [19].

$$
V_{w}=Q_{s t} \cdot P_{v}
$$

where $V_{w}$ is the ecological service value that can be provided by the ecological water consumption of the agricultural water savings in yuan; $Q_{s t}$ is the amount of agricultural water savings transferred to ecological water consumption in $\mathrm{m}^{3}$; and $P_{v}$ is the value of domestic water for residents in yuan $/ \mathrm{m}^{3}$.

The service value of the cultivated land ecosystem includes a positive value and negative value. The positive value is mainly derived from the value of agricultural products. Under the government's water management scheme, the positive value is zero. The negative value mainly comes from water consumption and fertilizer application, which combined account for about $84.16 \%$ of the total negative value [38]. According to the fourth assessment report of the United Nations Panel on Climate Change (IPCC), agricultural activities account for $13.5 \%$ of all greenhouse gas emissions caused by human activities [IPCC, 2007], and about $60 \%$ of $\mathrm{CH}_{4}$ and $61 \%$ of $\mathrm{N}_{2} \mathrm{O}$ in major greenhouse gas emissions come from agricultural production. Moreover, the warming potentials of $\mathrm{CH}_{4}$ and $\mathrm{N}_{2} \mathrm{O}$ on a 100-year scale are 25 times and 298 times that of $\mathrm{CO}_{2}$, respectively [IPCC, 2007, 2013]. Studies have shown that $\mathrm{CH}_{4}$ mainly comes from emissions from paddy fields, and $\mathrm{N}_{2} \mathrm{O}$ mainly comes from emissions from dry land [17]. Because this study focused on dry land cultivation in arid areas, only the negative value of $\mathrm{N}_{2} \mathrm{O}$ emissions was considered. Moreover, the $\mathrm{CO}_{2}$ emitted by the respiration of the cultivated land ecosystem is much less than the $\mathrm{CO}_{2}$ consumed by its photosynthesis, regardless of the amount of $\mathrm{CO}_{2}$ emissions. In reference to the work of Qi [39] and Min [40] regarding the calculation methods of greenhouse gas emissions from agricultural production in China and the value of China's farmland ecosystems, it is proposed that the negative value of $\mathrm{N}_{2} \mathrm{O}$ that can be generated and the negative value of fertilizer use under the government's water resources management scheme are calculated as follows:

Negative value of greenhouse gas $\mathrm{N}_{2} \mathrm{O}$ emissions:

$$
V_{\mathrm{N}_{2} \mathrm{O}}=P_{c} \cdot G_{w p} \cdot M_{D} \cdot F_{N_{2} \mathrm{O}} \cdot 27.27 \%
$$

where $V_{\mathrm{N}_{2} \mathrm{O}}$ is the negative value of $\mathrm{N}_{2} \mathrm{O}$ greenhouse gases in yuan; $P_{c}$ is the carbon trading price (the average cost of afforestation in China (273.3 yuan/t carbon) was obtained [41]) in yuan $/ \mathrm{kg} ; G_{w p}$ is the global warming potential of $\mathrm{N}_{2} \mathrm{O}$ greenhouse gases, expressed in $\mathrm{kg}$ (calculated as $\mathrm{CO}_{2}$ ) (using the warming potential to convert the same quality of $\mathrm{N}_{2} \mathrm{O}$ gas into the equivalent $\mathrm{CO}_{2}$ greenhouse effect, the warming effect of $1 \mathrm{~kg} \mathrm{~N} \mathrm{~N}_{2} \mathrm{O}$ is 298 times that of $1 \mathrm{~kg} \mathrm{CO} 2$ [IPCC, 2007]; therefore, take $\mathrm{CO}_{2}$ as 1 , and $\mathrm{N}_{2} \mathrm{O}$ as 298); $27.27 \%$ is the mass fraction of $\mathrm{C}$ in $\mathrm{CO}_{2} ; M_{D}$ is the planned area of irrigated land to be retired in 2020; and $F_{\mathrm{N}_{2} \mathrm{O}}$ is the emissions of dryland crops (when fertilizing) in $\mathrm{kg} / \mathrm{hm}^{2}$.

The negative value of the cultivated land ecosystem produced by the use of chemical fertilizers: As a result of the low utilization rate for chemical fertilizers, the unused part accumulates or migrates into the soil over time, causing a large amount of nitrogen loss and non-point-source agricultural pollution [42-44]. The negative value of unused fertilizers is calculated as follows:

$$
V_{h f}=\sum_{i=1}^{n} P_{h f i} \cdot M_{D} \cdot(1-t)
$$

where $V_{h f}$ is the negative value of ecosystem services produced by the application of chemical fertilizers in yuan; $P_{h f i}$ is the price of different fertilizer types in yuan $/ \mathrm{hm}^{2} ; n=5$; 
$M_{D}$ is the planned area of land retired in the irrigation district in $\mathrm{hm}^{2}$; and $t$ is the fertilizer utilization rate.

The total value of the relative increase in ecosystem services: Under systems theory and ecological environmental externality benefits [45], returning land and water reduction measures can reduce greenhouse gas emissions and soil environmental damage, thus playing a positive role in sustainable economic and social development.

$$
V_{s t}=V_{w}+V_{N_{2} O}+V_{h f}
$$

where $V_{s t}$ is the total value that the ecosystem service can increase in yuan. The rest of the symbols are the same as above.

\section{Results and Discussion}

\subsection{Analysis of Regional Agricultural Water-Saving Potential}

On the basis of our team's previous research results [46], compared with the actual irrigation volume of the current farmland in the irrigation area, 22,642,200 $\mathrm{m}^{3}$ of surplus water (approximately 15\%) can be saved under the irrigation management quota. According to the Work Plan for Retiring Land and Water Reduction of the Eighth Division of Xinjiang Construction Corps and the Urban Master Plan of Shihezi City, the Manas River Basin (Shihezi Irrigation District, Xiayedi Irrigation District, and Mosuowan Irrigation District) of the Eighth Division has a planned land reclamation area of $17,333.4 \mathrm{hm}^{2}$ in 2020, and the planned land reclamation area of each irrigation area is taken as an average of $5777.8 \mathrm{hm}^{2}$. The cotton irrigation water quota is based on the Xinjiang Uygur Autonomous Region Local Standard Agricultural Irrigation Water Quota. The cotton net irrigation water quota is $3375 \mathrm{~m}^{3} / \mathrm{hm}^{2}$ at the southern edge of the Junggar Basin in northern Xinjiang under the irrigation guarantee rate of 50\% [47]. Substituting the above data into Equations (1) and (2), the regional agricultural water savings were calculated to be $52,504,500 \mathrm{~m}^{3}$.

According to Yang's [48] water demand calculation results for the Shihezi Irrigation District in the Manas River Basin in 2020 (Table 1), the ratio of industrial and ecological increased water in this area over many years was taken as the specific value of the water that should be transferred from the agricultural water-saving amount to industrial and ecological water. From 2010 to 2020, industrial water use in the irrigation area increased by $139,041,000 \mathrm{~m}^{3}$ and the ecological water demand increased by $7,125,300 \mathrm{~m}^{3}$. Therefore, the ratio of industrial and ecological multitransfer was 0.95:0.45. Substituting into Equations (3) and (4), $Q_{g y}$ is $49,879,300 \mathrm{~m}^{3}$ and $Q_{s t}$ is $2,625,200 \mathrm{~m}^{3}$.

Table 1. Water demand of the Shihezi Irrigation District in $2020\left(10^{4} \mathrm{~m}^{3}\right)$.

\begin{tabular}{ccccc}
\hline Horizontal Year & Irrigation District Name & Agriculture & Industry & Ecology \\
\hline 2010 & Shihezi Irrigation District & $24,681.8$ & 6933.4 & 4543.77 \\
2020 & Shihezi Irrigation District & $27,307.8$ & $20,837.5$ & 5256.3 \\
\hline Note: 2010 is the base year. Data source: Reference [48].
\end{tabular}

A lower agricultural water price is not conducive to improving farmers' awareness of the need to save water during irrigation; it is one of the reasons for the large volumes of irrigation water used. According to the game theory method, when the agricultural water price in an irrigation area is increased to the full-cost water price, the actual irrigation volume and quota management irrigation volume tend to remain consistent and $15 \%$ surplus water can be saved [49], which verifies the rationale of $15 \%$ of agricultural surplus water under the irrigation management quota in this irrigation area. Moreover, there is still a gap between the agricultural irrigation water utilization coefficient of the irrigation area and the international advanced level. With the completed improvements to the canal system of the irrigation area and the optimization of the irrigation system and irrigation equipment under the current irrigation water quota, there is still a potential further improvement in water saving. Secondly, according to the plan to reduce unconventional arable land in the 
region in 2020, the amount of reduced water is a fixed value. The amount of surplus water saved under the returning land and water reduction measures should be a dynamic value based on the area of returned land year to year. In general, the agricultural water-saving potential in this region is great.

Water rights trading between the industrial and agricultural sectors is currently considered the most effective form of water trading [3]. This article used the added value of industrial and ecological water use in the region over the next 10 years (using 2010 as the base year) as the two available bases for the amount of water obtained from agricultural water savings. Approximately $95 \%$ of agricultural water savings are transferred to economic development needs and $5 \%$ of water savings are transferred to eco-environmental water needs, which is in line with the most effective trading mode of water and the regional demand for water resources. However, from the final value and advantages of the two, it can be seen that the ecological value of $5 \%$ of the transferred fresh water accounts for $16.7 \%$ of the value of $95 \%$ of the transferred industrial water. As researchers begin to consider independent systems such as water, soil, atmosphere, economy, and society from a systematic perspective $[22,23,50]$, ecological value can be seen to play an increasingly important role in the overall system. In addition, human beings are developing an increasingly profound understanding of the harmonious ecological environment, humanity and water, and humanity and nature. In the initial water rights allocation of the basin and with the continuous refinement of ecological environment indicators, the amount of water that can be transferred to ecological needs will gradually increase, which provides a benefit for the restoration of ecosystem service value in the whole arid oasis area.

\subsection{Industrial Benefit Analysis}

With the continuous improvement of China's water rights trading market and the gradual maturity of the water rights trading system, the core issue in water rights trading, namely the transaction price, has been extensively studied by scholars. According to Zhang's $[15,16]$ research results on pricing models for water rights transactions between China's agricultural and industrial sectors, the water price to be paid for turning agricultural water into industrial water is an interval value: $0.74-1.10$ yuan $/ \mathrm{m}^{3}$ and 0.68 1.22 yuan $/ \mathrm{m}^{3}$. Taking the average value between the two as the industrial transaction water value in this study $\left(0.935 \mathrm{yuan} / \mathrm{m}^{3}\right), P_{n}$ represents the current value of agricultural irrigation water in the irrigation area: $0.25 \mathrm{yuan} / \mathrm{m}^{3}$. According to statistics from the Xinjiang Water Resources Bulletin in 2018, the value-added water consumption of the 10,000 yuan water industry in the Shihezi area is $58.20 \mathrm{~m}^{3}$ [51]. From Equations (5), (6), and (7), it can be concluded that the industrial benefits that can be generated by water trading in this area are equal to 35,024,300 yuan.

A large proportion of agricultural water savings has been reallocated to the industrial sector, which has produced considerable economic benefits. However, this process has reduced the current water consumption of farmers and increased the cost input of watersaving facilities, which impacts the interests of farmers. Compensation for agriculture is an important issue. Robert [52] analyzed the phenomenon of agricultural water rights transactions in Chile. He proposed a system to establish an equivalent exchange mechanism through the water rights market to meet nonagricultural water use needs while protecting the interests of farmers. Mattia [53] analyzed the phenomenon of agricultural water rights trading in India and concluded that the relevant departments must issue a series of compensation policies to compensate for the development of irrigated agriculture. On the whole, a market-oriented mechanism should be established through which "agricultural water-saving promotes industrial development, and industrial development feeds back agricultural modernization."

\subsection{Eco-Environmental Benefit Analysis}

Concerning the Shihezi Statistical Yearbook 2018 of the Eighth Division of Xinjiang Production and Construction Corps [54], the domestic water price in Shihezi City is 
2.22 yuan $/ \mathrm{m}^{3}$. Therefore, from Equation (8), the value of the freshwater ecosystem services provided by the water resources of the agricultural water savings transferred to the ecological sector is equal to $5,828,800$ yuan.

The calculated negative value of the cultivated land ecosystem service includes the negative value caused by greenhouse gas emissions and the negative value caused by soil environmental pollution. According to experimental research by Huang [55], Yu [56], and other scholars, $\mathrm{N}_{2} \mathrm{O}$ emissions from dryland crops (without fertilization) are equal to $0.95 \mathrm{~kg} / \mathrm{hm}^{2}$. The costs of different types of fertilizers per hectare of cotton were obtained from the Compilation of National Agricultural Product Costs and Benefits 2018 (Table 2). According to the research results of Qi [43], the fertilizer utilization rate is $34.17 \%$; from Equations (9) and (10), the negative value of greenhouse gas $\mathrm{N}_{2} \mathrm{O}$ emissions was calculated to be equal to $1,219,100$ yuan, and the negative value of chemical fertilizers was equal to $12,535,100$ yuan. Wang [57] and Liu [38] considered the greenhouse gas emissions generated by fertilization during the growth period of crops when calculating the negative value of the cultivated land ecosystem services in China; these studies imply that the values for greenhouse gas emissions in this paper are conservative.

Table 2. Fertilizer price of cotton per hectare (yuan $/ \mathrm{hm}^{2}$ ).

\begin{tabular}{cccccc}
\hline $\begin{array}{c}\text { Fertilizer } \\
\text { Type }\end{array}$ & $\begin{array}{c}\text { Nitrogen } \\
\text { Fertilizer }\end{array}$ & $\begin{array}{c}\text { Phosphate } \\
\text { Fertilizer }\end{array}$ & $\begin{array}{c}\text { Potash } \\
\text { Fertilizer }\end{array}$ & $\begin{array}{c}\text { Compound } \\
\text { Fertilizer }\end{array}$ & $\begin{array}{c}\text { Other } \\
\text { Fertilizers }\end{array}$ \\
\hline price & 794.25 & 14.85 & 64.5 & 1843.2 & 578.85 \\
\hline
\end{tabular}

Data source: Compilation of Costs and Benefits of National Agricultural Products 2018.

The total value of the relative increase in ecosystem services is equal to 19,482,200 yuan, according to Equation (11). It can be seen that under the water management scheme implemented by the government, the value of transferring agricultural water savings to the industrial and ecological sectors through water trade is equal to $54,606,500$ yuan.

In the context of environmental protection goals, the value of freshwater resource ecosystem services is very considerable. The restoration of the ecosystem is a relatively long process. The overexploitation of water resources has had an adverse effect on the ecological environment [58], especially in the lower reaches of the basin [59]. Chen [60] cited the Tarim River Basin in Xinjiang as an example in a study showing that the decline of the groundwater level in the lower reaches of the basin had a significant impact on vegetation degradation. For inland river basins in arid oasis areas, water resources are mainly supplied from snowmelt in mountainous areas close to the oases. It is very difficult to replenish water through external water transfer, which can cause other forms of environmental damage. Due to human over-reclamation, global warming and the frequent occurrence of extreme weather have seriously affected the atmospheric hydrological cycle. The value of farmland environmental pollution caused by chemical fertilizers and plastic films exceeds the value of basic services to the farmland ecosystem, which increases farmland productivity to a certain extent but also aggravates the carrying load of the farmland ecosystem [20]. Simultaneously, excessive wasteland reclamation by humans causes damage to the service function value of the original desert ecosystems, such as value associated with raw salt production, water conservation, and climate regulation [42]. The measures of returning land and reducing water have not only reduced the unreasonable use of water resources and the pollution of farmland ecological environments, but also played a positive role in reducing greenhouse gas emissions. Previous researchers found that the interprovincial water transaction cost is high [5]; most arid oasis areas belong to inland river basins, and the water rights transaction is basically considered at the same level of jurisdiction, or at an even smaller scope. Therefore, the water rights transaction model constructed in this paper has a wide application value for different arid areas. 


\section{Conclusions}

As the temperature rises and water resources deteriorate worldwide, an increasing number of regions are making plans to implement water consumption controls. On the basis of determining land by water, combined with the development status of Xinjiang's economic society and ecological environment, the water rights trading model constructed for this arid oasis area has a certain practical guiding value for water resource management in other arid oasis areas. To a certain extent, the goal of returning land and reducing water has reduced the overexploitation and over-reclamation of land, the unreasonable utilization of water resources, and the pollution of original land by human beings, and has made a positive contribution to the restoration of regional ecological environment. It is feasible to evaluate the overall benefit of agricultural water saving for regional sustainable development via water rights trading in combination with relevant measurement indexes.

Under the most stringent water resource management and the goal of returning land and reducing water, the total agricultural water saved in the study area was 52,504,500 $\mathrm{m}^{3}$; thus, $49,879,300 \mathrm{~m}^{3}$ can be diverted to the industrial sector and $2,625,200 \mathrm{~m}^{3}$ to the ecological sector. Through the water trading method, regional agricultural water saving can generate an industrial value equal to $35,024,300$ yuan, an ecosystem service value equal to $19,482,200$ yuan, and an overall benefit equal to $54,606,500$ yuan. Furthermore, the above values are relatively conservative. The contribution of freshwater resources to other industries should be considered in depth in future research. With the construction of national standard for farmland, the optimization of the agricultural planting structure, innovation in industrial water technology, and the continuous improvement of government water resource management, we expect to see be more and more water rights transactions between different departments and industries, and within departments and industries. Water trading can be used to optimize the structure of water use management and to achieve sustainable development of the water resources-economic society-ecological environment system in arid oasis areas.

Author Contributions: C.W. and X.H. contributed to conceiving and designing the approach in this paper. H.L. provided guidance on the calculation methods of farmland soil. J.Z. compiled the relevant data of this article. T.H. and Z.W. made a draft of pictures and text. All authors have read and agreed to the published version of the manuscript.

Funding: This research was funded by the National Key Research and Development Plan of China (2017YFC0404304), the National Natural Science Foundation of China-Xinjiang Joint Fund (U1203282), and the Scientific and Technological Research Project in Key Fields of the Corps (2018AB027).

Acknowledgments: The anonymous reviewers and the editor are thanked for providing insightful and detailed reviews that greatly improved the manuscript.

Conflicts of Interest: The authors declare no conflict of interest.

\section{References}

1. Tortajada, C.; Biswas, A.K. COVID-19 heightens water problems around the world. Water Int. 2020, 45, 441-442. [CrossRef]

2. Scheierling, S.; Treguer, D.; Booker, J.; Decker, E. How to Assess Agricultural Water Productivity? Looking for Water in the Agricultural Productivity and Efficiency Literature; World Bank Policy Research Working Paper; The World Bank: Washington, DC, USA, 2014; p. 6982.

3. Wang, Y.H. A simulation of water markets with transaction costs. Agric. Water Manag. 2012, 103, 54-61. [CrossRef]

4. Grafton, R.Q.; Libecap, G.; McGlennon, S.; Landry, C.; O’Brien, B. An Integrated Assessment of Water Markets: A Cross-Country Comparison. Rev. Environ. Econ. Policy 2011, 5, 219-239. [CrossRef]

5. Wheeler, S.A.; Loch, A.; Crase, L.; Young, M.; Grafton, R.Q. Developing a water market readiness assessment framework. J. Hydrol. 2017, 552, 807-820. [CrossRef]

6. Connell, D. Irrigation, water markets and sustainability in Australia's Murray-Darling Basin. Agric. Agric. Sci. Procedia 2015, 4, 133-139. [CrossRef]

7. Wheeler, S.A.; Carmody, E.; Grafton, R.Q.; Kingsford, R.T.; Zuo, A. The rebound effect on water extraction from subsidising irrigation infrastructure in Australia. Resour. Conserv. Recycl. 2020, 159, 17. [CrossRef]

8. Grafton, R.Q.; Horne, J.; Wheeler, S.A. On the Marketisation of Water: Evidence from the Murray-Darling Basin, Australia. Water Resour. Manag. 2016, 30, 913-926. [CrossRef] 
9. Zeng, X.T.; Li, Y.P.; Huang, G.H.; Liu, J. Modelling Water Trading under Uncertainty for Supporting Water Resources Management in an Arid Region. J. Water Resour. Plan. Manag. 2016, 142, 04015058. [CrossRef]

10. Chen, B. Research on Market-Type Water Rights Trading Method; Tsinghua University: Beijing, China, 2017. (In Chinese)

11. Liu, X.C.; Tan, H.O.; Liu, H.L.; Zhang, S.J.; Wang, J.; Lin, H.X. Research on Water Rights Transaction Model Based on Nash Negotiation Solution-Taking Jining as an Example. China Rural Water Hydropower 2018, 5, 196-199. (In Chinese)

12. Wu, F.P.; Yu, Q.W.; Shen, J.Y.; Zhang, L.N. Research on the Theoretical Framework of Water Rights Transaction Price Formation Mechanism Based on Market Orientation. China Popul. Resour. Environ. 2018, 28, 17-25. (In Chinese)

13. Xu, Z.Y.; Lian, J.J.; Bin, L.L.; Hua, K.X.; Xu, K.; Chan, H.Y. Water Price Prediction for Increasing Market Efficiency Using Random Forest Regression: A Case Study in the Western United States. Water 2019, 11, 228. [CrossRef]

14. Shen, J.Y.; Wu, F.P.; Yu, Q.W.; Zhang, Z.F.; Zhang, L.; Zhu, M.; Fang, Z. Standardization of Exchanged Water with Different Properties in China's Water Rights Trading. Int. J. Environ. Res. Public Health 2020, 17, 1730. [CrossRef]

15. Zhang, W.G.; Mao, H.C.; Yin, H.J.; Guo, X.W. A pricing model for water rights trading between agricultural and industrial water users in China. J. Water Supply Res. Technol. Aqua 2018, 67, 347-356. [CrossRef]

16. Zhang, W.G.; Tan, L.; Yin, H.J.; Guo, X.W. Study on the price of water rights trading between agriculture and industry based on emergy theory. Water Supply 2019, 19, 2044-2053. [CrossRef]

17. Zhao, X. Research on the Effect and Potential of Soil Carbon Sequestration and Emission Reduction of Conservation Tillage Farmland in My Country Based on Meta-Analysis; China Agricultural University: Beijing, China, 2017.

18. Lichen, C.; Jie, D.; Xiaoyan, Q.; Aliakbar, K.; Xuping, Z. Achieving sustainable soil and water protection: The perspective of agricultural water price regulation on environmental protection. Agric. Water Manag. 2021, 245, 106583. [CrossRef]

19. Xiao, S.C.; Xiao, H.L.; Lu, Q.; Li, S.; Wei, H. Hydrological control function and service value evaluation of China desert (land) ecosystem. J. Desert Res. 2013, 33, 1568-1576. (In Chinese)

20. Shi, F.X.; Song, C.C.; Zhao, C.Z.; Zhang, J.; Shi, L.L. Dynamic of Service Value of Farmland Meta-ecosystem of Mountain, Oasis and Desert and Multiple Regression Analysis of the Influence Factors in the Hexi Corridor, Gansu, China. J. Desert Res. 2013, 33, 1598-1604. (In Chinese)

21. Costanza, R.; D’Arge, R.; de Groot, R.; Farber, S.; Grasso, M.; Hannon, B.; Limburg, K.; Naeem, S.; O’Neill, R.V.; Paruelo, J.; et al. The value of the world's ecosystem services and natural capital. Ecol. Econ. 1998, 25, 3-15, reprinted in Nature 1997, $387,253$. [CrossRef]

22. Nepal, S.; Neupane, N.; Belbase, D.; Pandey, V.P.; Mukherji, A. Achieving water security in Nepal through unravelling the water-energy-agriculture nexus. Int. J. Water Resour. Dev. 2021, 37, 67-93. [CrossRef]

23. Li, J.W.; Zuo, Q.T.; Ma, J.X. Analysis on the Characteristics of the Temporal and Spatial Evolution of Xinjiang Water ResourcesEconomic Society-Ecological Environment. J. Beijing Norm. Univ. (Nat. Sci.) 2020, 56, 591-599. (In Chinese)

24. Li, J.W. Research on the Relationship between the Temporal and Spatial Evolution and Mutual Feedback of Water Resources, Economic Society and Ecological Environment in Xinjiang; Zhengzhou University: Zhengzhou, China, 2020. (In Chinese)

25. Wang, Y.h.; Shu, Q.F.; Wu, J.Z. Review of Water Rights Market Research and Prospects of Water Rights Market Research with Chinese Characteristics. China Popul. Resour. Environ. 2017, 27, 87-100. (In Chinese)

26. Yu, Y.W.; Wei, J.Z. Analysis of the impact of agricultural supply-side reforms on changes in cotton production quality in my country. Chin. J. Agric. Resour. Reg. Plan. (In Chinese).

27. National Bureau of Statistics of the People's Republic of China. Announcement of the National Bureau of Statistics on Cotton Production in 2020; National Bureau of Statistics: Beijing, China, 2020. Available online: http:/ / www.stats.gov.cn/tjsj/zxfb/202012/t2020121 8_1810113.html (accessed on 18 December 2020). (In Chinese)

28. Huang, J.P.; Ji, M.G.; Liu, Y.Z.; Zhang, L.; Gong, D.Y. A review of climate change research in arid and semi-arid regions. Clim. Chang. Res. 2013, 9, 9-14. (In Chinese)

29. Huang, J.P.; Yu, H.P.; Guan, X.D.; Wang, G.Y.; Guo, R.X. Accelerated dryland expansion under climate change. Nat. Clim. Chang. 2016, 6, 166. [CrossRef]

30. Tennant, D.L. Instream flow regimens for fish, wildlife, recreation, and related environmental resources. Fisheries 1976, 1, 6-10. [CrossRef]

31. Qian, Z.Y.; Zhang, G.D. Comprehensive Report on China's Sustainable Development of Water Resources Strategy and Various Special Reports; China Water\&Power Press: Beijing, China, 2001. (In Chinese)

32. Zhang, Q.L. Exploration and Practice of "Retreating Land and Reducing Water" Work of the Sixth Division of the Bingtuan. Xinjiang Farm Res. Sci. Technol. 2018, 41, 46-48. (In Chinese)

33. Xu, W.W. Research on the Countermeasures of Implementing Land Retirement and Water Reduction in Turpan City. Water Resour. Dev. Res. 2020, 20, 32-34. (In Chinese)

34. Ji, J.H. Calculation of Effective Utilization Coefficient of Agricultural Irrigation Water in Shihezi Reclamation Area. Water Sci. Eng. Technol. 2019, 3, 31-34. (In Chinese)

35. Xue, L.Q.; Ni, T.; Liu, Y.H.; Liao, S.M. Calculation of suitable scale of Oasis in Manas River Basin based on surface runoff forecast. Water Resour. Prot. 2021, 37, 7-13. (In Chinese)

36. Wu, F.; Chen, F.L.; Zhang, Z.J.; Long, A.H.; He, X.L. Water demand forecast of Shihezi City based on improved grey model. J. Water Resour. Water Eng. 2020, 31, 76-82. (In Chinese)

37. U.S. Environmental Protection Agency. Ecological Benefits Assessment Strategic Plan; EPA: Washington, DC, USA, 2006. 
38. Liu, L.H.; Zhang, B.X.; Liu, X.H. Research on China's Provincial Cultivated Land Protection and Compensation from the Perspectives of Food Security and Ecological Security. Trans. Chin. Soc. Agric. Eng. 2020, 36, 252-263. (In Chinese)

39. Qi, X.F. Analysis of the Spatio-temporal Changes and Influencing Factors of the Positive and Negative Service Values of Regional Farmland Ecosystem-Taking Shandong Province as an Example. Res. Agric. Mod. 2013, 34, 622-626. (In Chinese)

40. Min, J.S.; Hu, H. Estimation of Greenhouse Gas Emissions from Agricultural Production in China. China Popul. Resour. Environ. 2012, 22, 21-27. (In Chinese)

41. Hou, Y.Z.; Wang, Q. Research on China's Forest Resources Accounting. World For. Res. 1995, 3, 51-56. (In Chinese)

42. Wu, Y.; Li, F.; Zheng, H.C.; Hong, M.; Hu, Y.C.; Zhao, B.; De, H.S. Effects of three types of soil amendments on yield and soil nitrogen balance of maize-wheat rotation system in the Hetao Irrigation Area, China. J. Arid Land. 2019, 11, 904-915. [CrossRef]

43. Wang, Y.C.; Ying, H.; Yin, Y.L.; Zheng, H.F.; Cui, Z.L. Estimating soil nitrate leaching of nitrogen fertilizer from global metaanalysis. Sci. Total Environ. 2019, 657, 96-102. [CrossRef] [PubMed]

44. Maila, T.; Asya, T.; Fuchenyi, Y. Analysis on the influencing factors of the risk perception of over-fertilization by farmers in cotton areas-Based on a questionnaire survey of 446 cotton farmers in Xinjiang. Chin. J. Agric. Resour. Reg. Plan. 2016, 37, 38-42. (In Chinese)

45. Wang, X.K.; Yang, N.; Wu, F.; Ren, Y.F.; Wang, S.Y.; Bo, G.M.; Jiang, G.M.; Wang, Y.K.; Sun, Y.J.; Zhang, L.; et al. Ecological benefit and its evaluation: I. Ecological benefit and its characteristics. Acta Ecol. Sin. 2019, 15, 1-9. (In Chinese)

46. He, T.M.; Wang, C.X.; Zhang, J. Initial Water Right Allocation for Deep-level Agricultural Water Based on Genetic Algorithm Projection Pursuit Model Optimization-Taking Shihezi Irrigation District of the Eighth Division of Xinjiang Construction Corps example. Chin. J. Agric. Resour. Reg. Plan. 2020. Available online: http://kns.cnki.net/kcms/detail/11.3513.S.20201229.1134.002. $\mathrm{html}$ (accessed on 25 April 2021). (In Chinese).

47. DB65/3611-2014. Local Standard of Xinjiang Uygur Autonomous Region; Quality and Technical Supervision Bureau of Xinjiang Uygur Autonomous Region: Xinjiang, China, 2014. (In Chinese)

48. Yang, M.J.; Yang, G.; He, X.L.; Long, A.H.; Chen, J.C.; Wang, C.; Bruce, L. Manas River Basin Water Resources Regulation Based on Multi-dimensional Critical Regulation Model. J. Shihezi Univ. (Nat. Sci.) 2017, 35, 241-246. (In Chinese)

49. He, T.M.; Wang, C.X.; He, X.L.; Li, P.F.; Zhang, J.; Wang, Z.L. Evaluation of agricultural water price tolerance and water-saving potential based on full cost water price-Taking the Shihezi Irrigation District of the Eighth Division of Xinjiang Construction Corps as an example. Water Sav. Irrig. 2021, 3, 1-5. (In Chinese)

50. Xu, Z.C.; Chen, X.Z.; Liu, J.G.; Zhang, Y.; Chau, S.; Bhattarai, N.; Wang, Y.; Li, Y.J.; Connor, T.; Li, Y.K. Impacts of irrigated agriculture on food-energy-water- $\mathrm{CO}_{2}$ nexus across meta coupled systems. Nat. Commun. 2020, 11, 5837. [CrossRef] [PubMed]

51. Xinjiang Uygur Autonomous Region Water Resources Department. 2018 Xinjiang Water Resources Bulletin; Xinjiang Uygur Autonomous Region Water Resources Department: Xinjiang, China, 2019. (In Chinese)

52. Hearne, R.R. Water markets as a mechanism for intersectoral water transfers: The Elqui Basin in Chile. Paddy Water Environ. 2007, 5, 223-227. [CrossRef]

53. Celio, M.; Giordano, M. Agriculture-urban water transfers: A case study of Hyderabad, South-India. Paddy Water Environ. 2007, 5, 229-237. [CrossRef]

54. Gao, X.K.; Li, W.W.; Guo, F. Shihezi Statistical Yearbook (2018); Beijing China Statistics Press: Beijing, China, 2018. (In Chinese)

55. Huang, G.H.; Chen, G.X.; Wu, J.; Huang, B.; $\mathrm{Yu}, \mathrm{K} . W . \mathrm{N}_{2} \mathrm{O}$ and $\mathrm{CH}_{4}$ emission fluxes from typical dry farmland in Northeast China. J. Appl. Ecol. 1995, 4, 383-386. (In Chinese)

56. Yu, K.W.; Chen, G.X.; Yang, S.H.; Wu, J.; Huang, B.; Huang, G.H.; Xu, H. The role of several dryland crops in the field of $\mathrm{N}_{2} \mathrm{O}$ release and the impact of environmental factors. J. Appl. Ecol. 1995, 4, 387-391. (In Chinese)

57. Wang, Z.P. Estimation of $\mathrm{N}_{2} \mathrm{O}$ emissions from farmland in China. J. Ecol. Rural Environ. 1997, 13, 51-55. (In Chinese)

58. Huber-Sannwald, E.; Maestre, F.T.; Herrick, J.E.; Reynolds, J.F. Ecohydrological feedbacks and linkages associated with land degradation: A case study from Mexico. Hydrol. Process. 2006, 20, 3395-3411. [CrossRef]

59. Chou, K.F.; Zhang, Q.; Chen, X.; Sun, L. Characteristics and Trends of Ecological Environment Changes in the Arid Areas of Central Asia. Sci. Sin. (Terrae) 2006, S2, 133-139. (In Chinese)

60. Chen, Y.N.; Li, W.H.; Xu, H.L.; Liu, J.Z.; Zhang, H.F.; Chen, Y.P. The influence of groundwater on vegetation in the lower reaches of Tarim river, China. J. Geogr. Sci. 2003, 4, 542-549. (In Chinese) 